\title{
Correction to: mouse mammary tumour virus (MMTV) and human breast cancer with neuroendocrine differentiation
}

\author{
J. S. Lawson ${ }^{1 *}$, C. C. Ngan ${ }^{1}$, W. K. Glenn ${ }^{1}$ and D. D. $\operatorname{Tran}^{1,2}$
}

After publication of the original article [1], the authors realised their given names and family names were incorrectly transposed in the author list. The correct presentations of the authors' names are included in the author list of this correction article.

\footnotetext{
Author details

${ }^{1}$ School of Biotechnology and Biomolecular Sciences, University of New South Wales, Sydney, Australia. ${ }^{2}$ Douglass Hanly Moir Pathology, Sydney, Australia.
}

Received: 19 September 2017 Accepted: 19 September 2017 Published online: 06 October 2017

\section{Reference}

1. Lawson JS, Ngan CC, Glenn WK, Tran DD. Mouse mammary tumour virus (MMTV) and human breast cancer with neuroendocrine differentiation. Infect Agent Cancer. 2017;12:24. doi:10.1186/s13027-017-0135-8.

\footnotetext{
* Correspondence: james.lawson@unsw.edu.au

${ }^{1}$ School of Biotechnology and Biomolecular Sciences, University of New

South Wales, Sydney, Australia

Full list of author information is available at the end of the article
} 